\title{
Pembangunan Aplikasi Pengukur Ketinggian Benda Berbasis Android dengan Menggunakan Metode Trigonometri
}

\author{
Amras Mauluddin ${ }^{1}$, Irwin Supriadi ${ }^{2}$ \\ Program Studi Informatika ${ }^{1,2}$ \\ Universitas Langlangbuana J1. Karapitan No. 116 Bandung $^{1,2}$ \\ Email : amrasmauluddin@gmail.com ${ }^{1}$, irwinshared@gmail.com ${ }^{2}$
}

\begin{abstract}
ABSTRAK
Saat ini kita mengenal dua cara untuk mengukur ketinggian benda. Cara pertama adalah menggunakan busur dan tape measure. Busur digunakan untuk menghitung besar sudut, kemudian tape measure digunakan untuk menghitung jarak antara titik sudut dan benda yang diukur. Sedangkan cara yang kedua adalah menggunakan alat yang disebut dengan thedolit. Hasil pengukuran dengan cara kedua ini lebih akurat dibandingkan dengan cara pertama. Hal ini dikarenakan thedolit memiliki tingkat ketelitian yang baik. Namun kedua cara pengukuran tersubut memiliki beberapa kelemahan, yakni cara pertama memerlukan ketelitian yang cermat saat menghitung sudut dan cara yang kedua memiliki kelemahan dalam hal biaya.

Untuk dapat menutupi kelemahan tersebut, maka dibuatlah sebuah Aplikasi pengukur ketinggian berbasis android. Penggunaan aplikasi ini cukup sederhana dan tidak memerlukan biaya. Sehingga diharapkan Aplikasi ini dapat menjadi solusi yang lebih efektif dan efisien.

Aplikasi pengukur ketinggian benda ini penulis namakan dengan Simple Measure. Perangkat ini dibangun dengan menggunakan bahasa pemograman JAVA. Metode pengukuran yang digunakan adalah trigonometri. Selain itu juga SensorFusion digunakan sebagai library untuk mendeteksi sudut kemiringan.
\end{abstract}

Kata kunci : Android, Trinometri, thedolit, Simple Measure, Java

\section{ABSTRACT}

At present we know two ways to measure the height of objects. The first way is to use a bow and tape measure. Arc is used to calculate the angle, then the tape measure is used to calculate the distance between the vertex and the object being measured. While the second way is to use a tool called thedolite. The measurement results in the second way are more accurate than the first method. This is because thedolite has a good level of accuracy. However, both methods of measurement have several disadvantages, namely the first method requires careful accuracy when calculating angles and the second method has weaknesses in terms of cost.

To be able to cover these weaknesses, then made an Android-based height gauge application. The use of this application is quite simple and requires no fees. So hopefully this application can be a more effective and efficient solution. 
This height measurement application is called a Simple Measure. This device was built using the JAVA programming language. The measurement method used is trigonometry. In addition, SensorFusion is used as a library to detect tilt angles.

Keywords: Android, Trinometry, thedolite, Simple Measure, Java

\section{PENDAHULUAN}

Trigonometri merupakan cabang ilmu matematika yang mempelajari tentang hubungan antara sudut-sudut segitiga terhadap ketiga bidang sisi-sisinya dan fungsi trigonometrik seperti sinus, cosinus dan tangen. Ditemukan sekitar 300 tahun yang lalu, konsep ini telah dimanfaatkan dalam berbagai bidang aspek keilmuan seperti ilmu fisika dan teknologi. Beberapa penerapan trigonometri tersebut antara lain digunakan pada ilmu astronomi untuk menghitung jarak bintang-bintang terdekat, dalam geografi menghitung antara titik tertentu dan grafik komputer serta masih banyak lagi aspek keilmuan lainnya.

Konsep trigonometri juga dapat digunakan untuk mengukur ketinggian sebuah benda. Contoh pengukuran ini seperti mengukur ketinggian sebuah gedung, pohon, menara dan lainnya. Dengan metode ini tentunya akan memudahkan seorang pengukur untuk mengetahui berapa tinggi suatu benda tanpa harus mengukurnya secara manual menggunakan tape measure atau alat yang sejenis.

Secara umum terdapat dua cara untuk mengukur ketinggian sebuah benda. Cara pertama yang digunakan adalah cara sederhana dengan menggunakan busur dan tape measure. Busur digunakan untuk menghitung besar sudut, sedangkan tape measure digunakan untuk menghitung jarak antara titik sudut dan benda yang diukur. Cara ini cukup mudah dilakukan dan peralatan yang digunakan pun mudah untuk didapatkan. Tetapi masih memiliki kekurangan yakni memerlukan ketelitian yang tinggi saat menghitung besar sudut dengan busur dan proses perhitungannya pun dilakukan secara manual sehingga kurang efektif dan efisien. Kemudian cara yang kedua adalah dengan menggunakan alat yang disebut dengan thedolit. Hasil pengukuran dengan cara kedua ini lebih akurat dibandingkan dengan cara pertama. Hal ini dikarenakan thedolit memiliki tingkat ketelitian yang baik. Namun pengukuran ini pun juga masih memiliki 
kelemahan, yakni memerlukan biaya untuk membeli alat tersebut. Untuk menutupi kekurangan dari kedua cara tersebut, diperlukan sebuah alat yang lebih efektif, efisien dan akurat tetapi tanpa mengeluarkan biaya (zero cost).

Dengan semakin berkembangnya teknologi saat ini memungkinkan alat yang dibutuhkan tersebut bisa didapatkan. Salah satu teknologi yang dapat menjadi solusi untuk masalah ini adalah smartphone Android. Android adalah smartphone canggih yang sangat populer saat ini. Android memiliki banyak sensor yang dapat dipadukan penggunaannya untuk mendeteksi kemiringan smartphone. Sensor-sensor tersebut yakni sensor accelerometer, gyroscope dan magnetic field. Dengan adanya sensorsensor ini, memungkinkan pengguna untuk dapat mengetahui berapa besar sudut di suatu titik terhadap benda yang diukur, sehingga hal ini memungkinkan metode pengukuran trigonometri dapat diimplementasikan pada pada Android.

Berdasarkan latar belakang yang telah diuraikan di atas, maka permasalahan yang muncul adalah bagaimana membuat sebuah alat ukur ketinggian yang dapat mengetahui memadukan penggunaan sensor accelerometer, gyroscope dan magnetic field untuk menghitung besar sudut kemiringan dengan metode trigonometri menggunakan aplikasi Android.

Berdasarkan hal tersebut peneliti bermaksud membuat sebuah aplikasi Android yang dapat mengukur ketinggian sebuah benda dengan menggunakan metode trigonometri. Hal itulah yang melatar belakangi peneliti dalam menyususun "Pembangunan Aplikasi Pengukur Ketinggian Benda Berbasis Android dengan Menggunakan Metode Trigonometri”.

Aplikasi adalah perangkat lunak yang memungkinkan penggunanya untuk melakukan pekerjaan yang spesifik ( dalam GCFLearnFree.org, Computer Basic : Understanding Application, : hal 1). Beberapa jenis aplikasi yang sering kita jumpai seperti aplikasi pengolah kata, musik, video dan lain sebagainya. Istilah aplikasi juga merujuk pada aplikasi kecil yang dirancang untuk ponsel seperti aplikasi Android, iPhone, Blackberry dan lain sebagainya.

Pengukuran adalah salah satu poin penting yang dipelajari dalam ilmu Fisika. Menurut Mirza Setiawan dalam bukunya yang berjudul Fisika Dasar (2012:6), mengukur adalah 
membandingkan antara dua hal, dengan salah satunya menjadi pembanding atau alat ukur, yang besarnya harus distandarkan. Mengukur membutuhkan standarisasi sebagai pembanding besar suatu yang diukur. Standar yang berlaku di seluruh dunia dikenal dengan Sistem Internasional (SI), bersamaan dengan itu juga terdapat satuan SI untuk setiap besaran fisika.

Trigonometri adalah ilmu yang memperlajari hubungan antara sisi dan sudut segitiga (Michael Corral, Trigonometry, 2009, Hal.1). Kata "Trigonometri” berasal dari bahasa Yunani trigono yang berarti "segitiga" dan metro yang berarti "mengukur".

$$
\begin{aligned}
& \sin \alpha=\frac{\text { depan }}{\text { miring }}=\frac{c}{b} \quad \csc \alpha=\frac{1}{\sin \alpha}=\frac{b}{c} \\
& \text { A } \\
& \cos \alpha=\frac{\text { samping }}{\text { miring }}=\frac{a}{b} \quad \sec \alpha=\frac{1}{\cos \alpha}= \\
& \tan \alpha=\frac{\text { depan }}{\operatorname{semping}}=\frac{c}{a} \quad \cot \alpha=\frac{1}{\tan \alpha}=\frac{a}{c}
\end{aligned}
$$

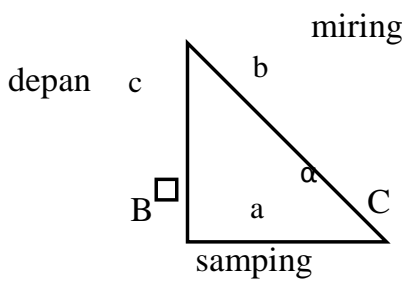

Gambar 1: Perbandingan Trigonometri pada segitiga siku-siku

Android adalah sistem operasi (SO) berbasis kernel linux yang saat ini dikembangkan oleh Google untuk smartphone. Android pertama kali dikembangkan pada tahun 2003 sebelum Google mengakuisisinya pada tahun 2005. Saat ini Android menjadi sistem operasi terpopuler yang digunakan. Itulah sebabnya mengapa saat ini banyak orang yang ingin mengembangkan aplikasi berbasis Android.

Arsitektur Android Sistem Operasi Android terdiri dari berapa susunan komponen software yang dibagi menjadi lima jenis komponen dalam empat layer utama.

Sensor Android secara garis besar terdapat tiga jenis sensor yang terdapat pada Android, yaitu : 


\section{Motion sensor}

Sensor ini dapat mengukur akselerasi dan rotasi pada tiga sumbu X, Y dan Z. Sensor yang termasuk kategori ini meliputi sensor accelerometers, gravity sensors, gyroscopes, dan rotational vector.

2. Environmental sensors

Sensor jenis ini dapat mengukur berbagai parameter lingkungan, seperti suhu udara dan tekanan, pencahayaan, serta kelembaban. Sensor kategori ini meliputi sensorbarometers, photometers, dan thermometers.

\section{Position sensor}

Sensor ini mampu mengukur posisi fisik perangkat. Kategori sensor ini meliputi sensor orientation dan magnetometers.

Sensor Accelerometer dapat mengukur percepatan dalam satuan $\mathrm{m} / \mathrm{s}^{2}$. Dalam hal ini percepatan didefinisikan sebagai tingkat perubahan kecepatan. Accelerometer mampu mengukur seberapa cepat kecepatan perangkat berubah dalam arah tertentu dan juga mendeteksi gerakan berdasarkan perubahan tingkat kecepatan tersebut. Perlu ditekankan bahwa accelerometer tidak dapat mengukur kecepatan.

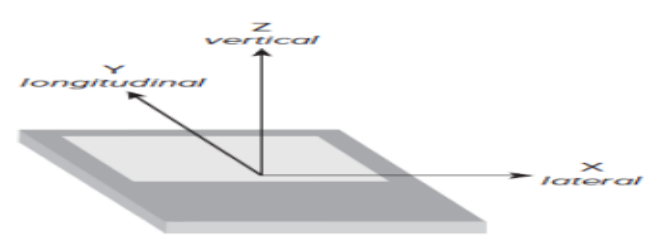

Gambar 2: Koordinat X,Y dan Z pada sensor Accelerometer

Sensor gyroscope dapat mengukur rotasi device pada sumbu $\mathrm{x}, \mathrm{y}$ dan $\mathrm{z}$ dalam satuan $\mathrm{rad} / \mathrm{s}$. Sistem koordinat sensor ini sama dengan sensor accelerometer, yakni pada sumbu x, y dan z. Namun berbeda dengan accelerometer, gyroscope tidak dipengaruhi oleh gaya gravitasi $(\mathrm{g})$. 
Sensor magnetic field memungkinkan kita untuk dapat memonitoring perubahan medan magnet bumi. Sensor ini juga memilki sumbu fisik yang sama yakni sumbu x, y dan z. Biasanya sensor ini tidak digunakan secara langsung. Akan tetapi nantinya akan dipadukan dengan dua sensor lainya untuk dapat menghitung besar sudut kemiringan.

\section{UML (Unified Modelling Language)}

UML dikenal sebagai bahasa standar untuk mendomentasikan, menspesifikasikan dan membangun perangkat lunak. UML digunakan untuk menentukan, menggambarkan, membangun dan mendokumentasikan suatu sistem. Berikut ini adalah macam-macam diagram UML, diantaranya :

1. Use Case diagram digunakan untuk memodelkan proses bisnis.

2. Conceptual diagram digunakan untuk memodelkan konsep-konsep yang terdapat pada aplikasi.

3. Sequence diagram untuk memodelkan pengiriman pesan antar objek.

4. Collaboration Diagram untuk memodelkan interaksi antar objek.

5. State Diagram untuk memodelkan perilaku objek di dalam sistem.

6. Activity Diagram untuk memodelkan perilaku Use Case dan objek di dalam sistem.

7. Class Diagram untuk memodelkan struktur kelas.

8. Object Diagram untuk memodelkan struktur objek.

9. Component Diagram untuk memodelkan komponen objek.

10. Deployment Diagram untuk memodelkan distribusi aplikasi.

\section{METODE PENELITIAN}

\subsection{Pengumpulan Data}

Dalam mengumpulkan data peneliti menggunakan 2 (dua) metode yaitu :

1. Metode Lapangan ( Field Research )

Peneliti melakukan pengamatan langsung berdasarkan pengalaman penulis pribadi dalam mengukur ketinggian tiang bendera dengan cara sederhana menggunakan alat busur. 


\section{Metode Perpustakaan ( Library research )}

Metode ini peneliti mengutip dari beberapa bacaan yang berkaitan dengan pelaksanaan penelitian, baik berupa teori ataupun beberapa pendapat dari beberapa buku yang dipergunakan selama kuliah. Hal ini dimaksudkan untuk memberikan landasan teori yang kuat melalui buku-buku atau literatur yang tersedia di perpustakaan. Selain itu juga dengan cara pengumpulan data dengan menggunakan fasilitas internet melalui mesin pencari (search engine).

\subsection{Pengembangan Sistem}

a. Model

Model yang digunakan dalam membangun Aplikasi ini adalah Prototype Model. Adapun alasan menggunakan model tersebut adalah sebagai berikut :

1. Waktu pembuatan sistem singkat yakni 12 minggu dan kebutuhan aplikasi belum dapat difahami seutuhnya, sedangkan pengembangan sistem harus tetap berjalan.

2. Membutuhkan feedback secara berkelanjutan selama proses pengembangan aplikasi

b. Metodologi

Metode yang digunakan dalam pengembangan sistem ini adalah Model Pemograman Berorientasi Objek.

\subsection{Metode Pengukuran Tinggi Benda}

Penelitian ini, peneliti menggunakan Trigonometri sebagai metode pengukuran. Metode ini begitu sederhana dan mudah untuk dilakukan. Untuk dapat menggunakan metode ini, kita terlebih dahulu harus mengetahui jarak benda terhadap posisi pengukuran dan juga besar sudut terhadap puncak tertinggi suatu benda.

\subsection{Penerapan Metode Pengukuran Tingi Benda Pada Android}

Dalam menerapkan metode trigonometri pada aplikasi Android ini, peneliti memanfaatkan sensor yang dimiliki oleh perangkat Android yakni sensor 
accelerometer, gyroscope dan magnetic field. Dengan algoritma tertentu, dapat menghasilkan besar sudut kemiringan smartphone yang dihasilkan oleh perpaduan dari ketiga sensor tersebut. Selain ketiga sensor tersebut, perangkat kamera juga diperlukan untuk membidik titik pada objek yang diukur.

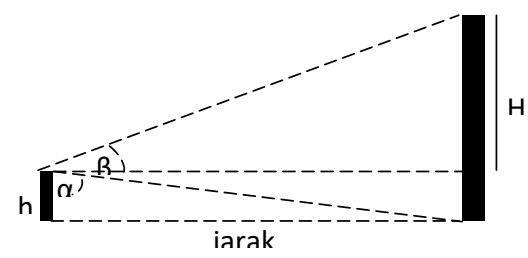

Gambar 3: Metode Gambar Trigonometri

Implementasi Metode Trigonometri Untuk Mengukur Tinggi Suatu Benda yang berdasarkan konsep dasar trigonometri diatas, maka kita dapat menggunakan persamaan $\tan \alpha=c / a$ sebagai metode untuk menghitung tinggi benda. Penjelasan dari persamaan tersebut dapat dijelaskan pada Gambar 4. Terdapat dua tahapan dalam menerapkan metode ini. Langkah pertama yakni mengukur jarak, sedangkan tahapan berikutnya yaitu mengukur tinggi.

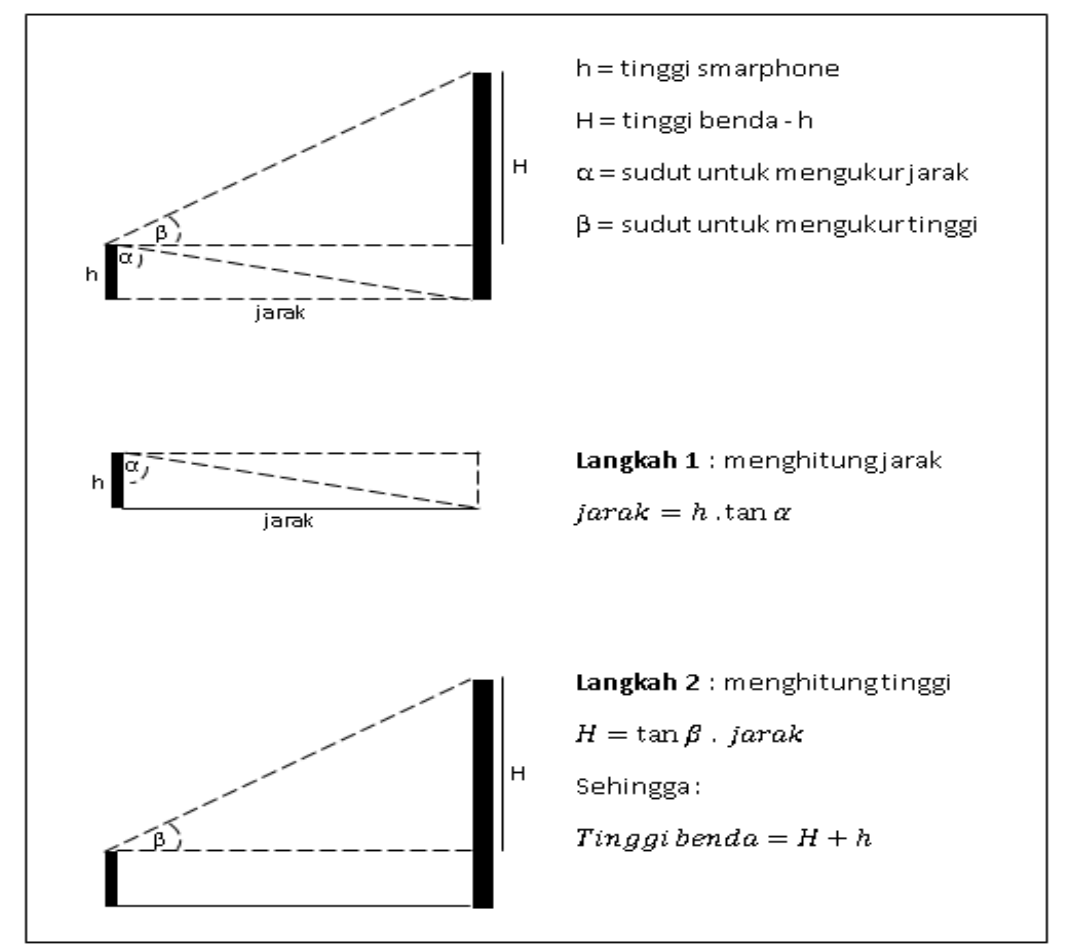

Gambar 4: Tahapan mengimlementasikan metode Trigonometri 


\subsection{Prototype Model}

Prototype model merupakan salah satu model pengembangan perangkat lunak. Model ini memumngkinkan developer dan pelanggan dapat saling berinteraksi dalam proses pembuatan perangkat lunak. Model pengembangan ini digunakan saat pengguna mendefiniskan kebutuhan umum sistem tetapi tidak mengidentifikasi kebutuhan secara rinci.

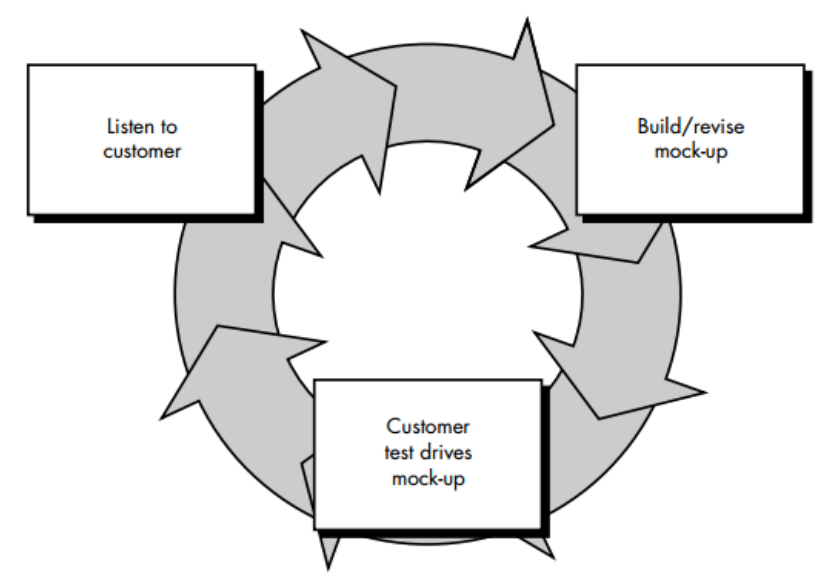

Gambar 5: Paradigma Prototype Model

Berikut ini tahapan-tahapan pengembangan perangkat lunak dengan menggunakan model prototype yang penulis rangkum dari buku Roger S. Pressman yang berjudul : Software engineering: a practitioner's approach (hal $30-31$ ) :

1. Analisa kebutuhan. Pelanggan dan pengembang bertemu untuk mendefinisikan kebutuhan perangkat lunak dan garis besar sistem yang akan dibuat.

2. Membangun prototyping. Membangun prototyping dengan membuat perancangan sementara yang berfokus pada penyajian kepada pelanggan.

3. Devloyment, delivery and feedback. Prototype yang telah dibangun diberikan kepada pelanggan untuk dievaluasi dan memberikan feedback tentang prototype tersebut. Evaluasi juga juga diperlukan untuk mengetahui apakah prototyping yang sudah dibangun sudah sesuai dengan keinginann pelanggan. 


\section{HASIL DAN PEMBAHASAN}

\subsection{Use Case Diagram}

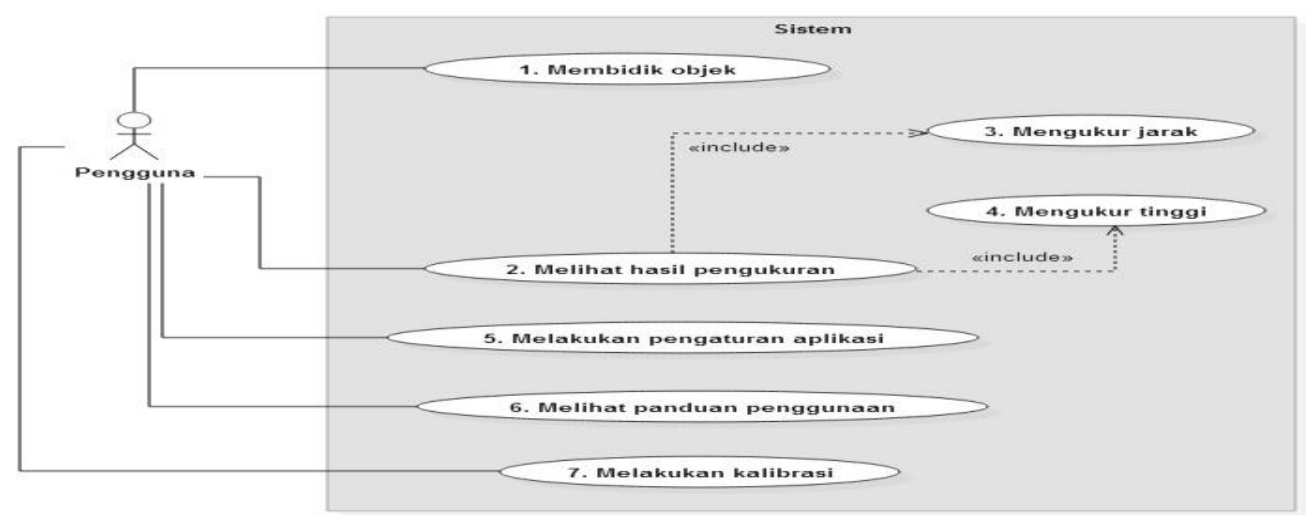

b

Gambar 6: Use Case Diagram

\subsection{Diagram Activity}

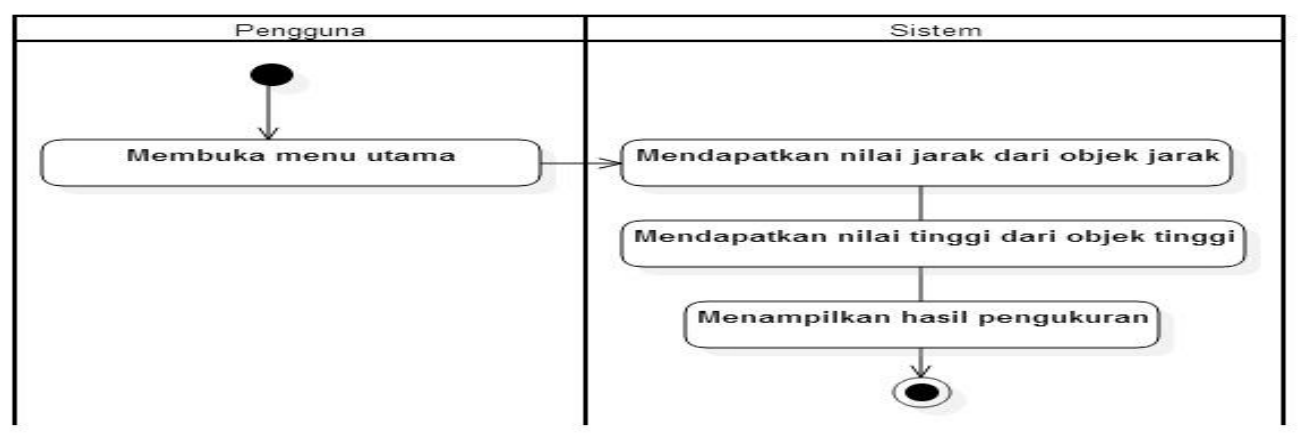

Gambar 7: Activity Diagram Lihat Hasil Pengukuran 


\subsection{Diagram Sequence}

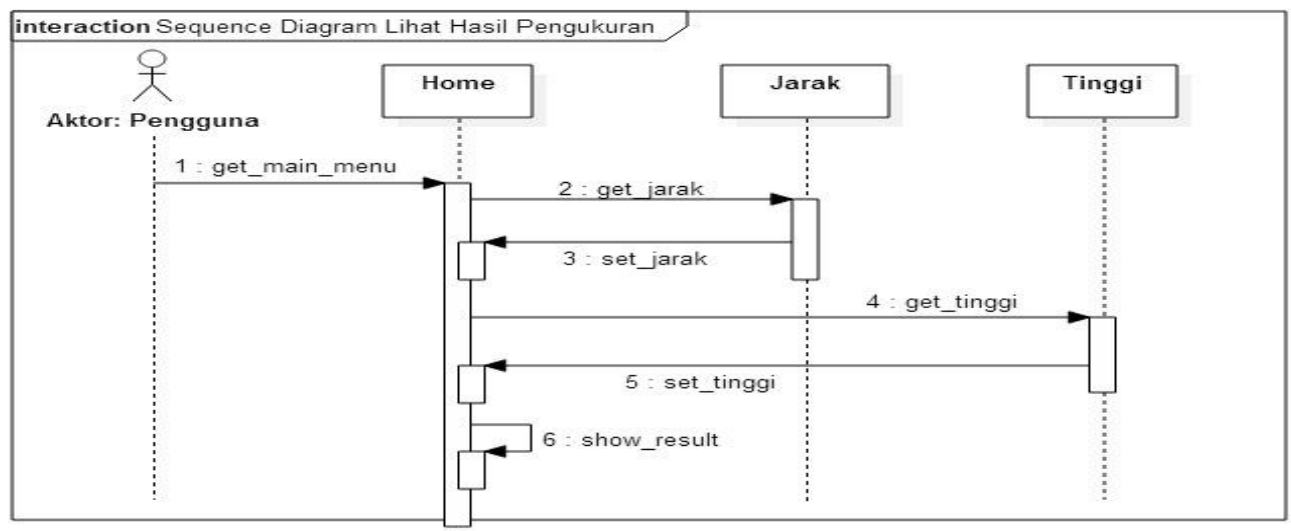

Gambar 8. Sequence Diagram Lihat Hasil Pengukuran

\subsection{Class Diagram}

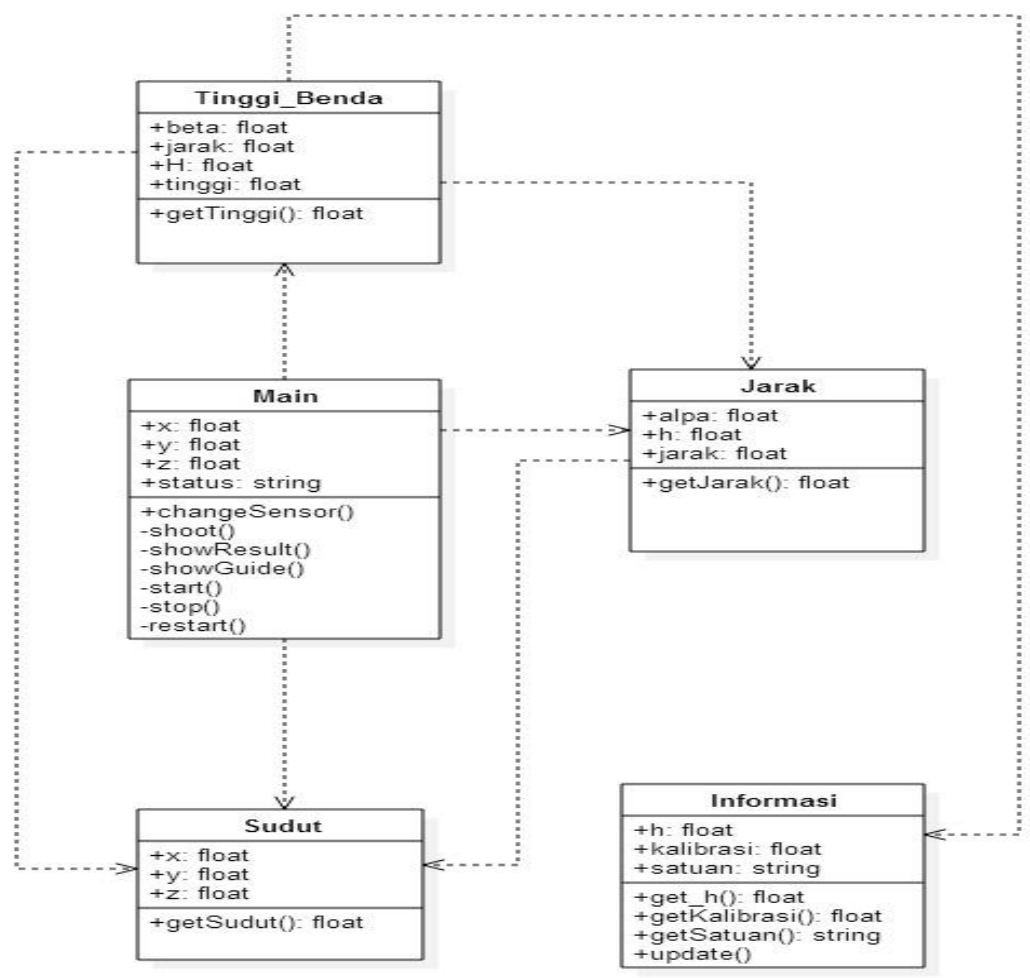

Gambar 9: Class Diagram 


\subsection{Perancangan Antar Muka}

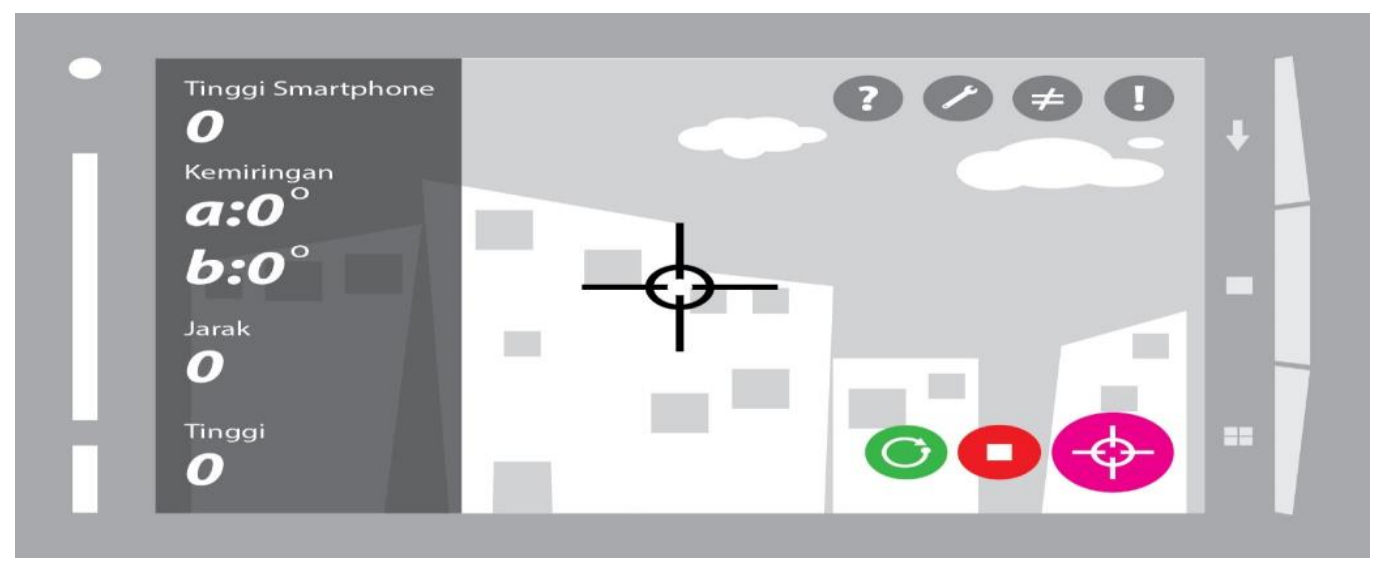

Gambar 10: Rancangan Tampilan Utama

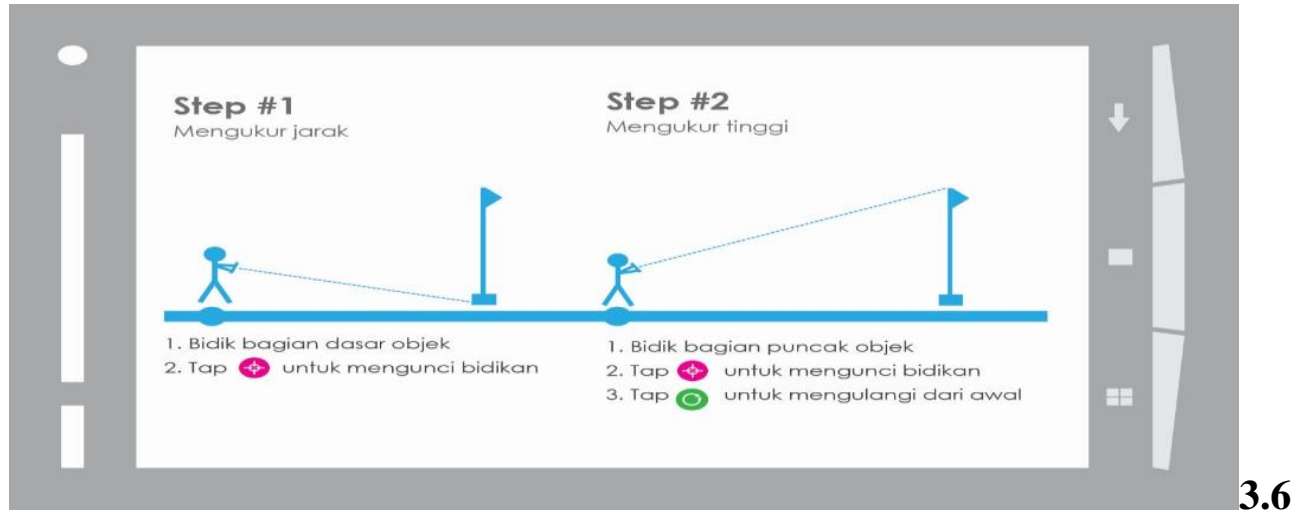

Gambar 11: Rancangan Tampilan Panduan Penggunaan

\subsection{Deskripsi dan Hasil Pengujian}

Deskripsi dan hasil pengujian menjelaskan bagaimana pelaksanaan dan hasil pengujian kebutuhan fungsional sistem. 
Tabel 1. Deskripsi dan hasil pengujian modul hasil pengukuran (output)

\begin{tabular}{|l|l|l|}
\hline $\begin{array}{l}\text { Nama } \\
\text { modul }\end{array} \quad$ : Hasil pengukuran (Output) \\
\hline \multicolumn{4}{|c|}{ Skenario } \\
\hline Tujuan $\quad$ : Untuk menampilkan hasil pengukuran \\
\hline \multicolumn{4}{|c|}{ Hasil } \\
\hline $\begin{array}{l}\text { 1. Melakukan pengukuran jarak } \\
\text { 2. Melakukan pengukuran tinggi } \\
\text { 3. Hasil pengukuran ditampilkan }\end{array}$ \\
\hline \multicolumn{4}{|c|}{ Pengamatan } & Kesimpulan \\
\hline $\begin{array}{c}\text { Yang } \\
\text { diberikan }\end{array}$ & Yang diharapkan \\
\hline $\begin{array}{l}\text { Jarak, } \\
\text { Tinggi }\end{array}$ & $\begin{array}{l}\text { Hasil pengukuran } \\
\text { ditampilkan saat } \\
\text { proses pengukuran }\end{array}$ & $\begin{array}{l}\text { Sistem OK } \\
\text { menampilkan } \\
\text { pengukuran }\end{array}$ \\
\hline
\end{tabular}

\section{SIMPULAN}

Dengan penggunaan Aplikasi Android merupakan salah satu solusi alat pengukur ketinggian benda. Pendeteksian kemiringan pada perangkat Android menggunakan library SensorFusion. yang dapat menggabungkan tiga sensor Android yakni accelerometer, gyroscope dan magnetic field. Pengukuran dengan menerapkan metode trigonometri ini pada aplikasi Android, yang dapat mengukur ketinggian benda yang lebih epektif dan efisien

\section{DAFTAR PUSTAKA}

Bahamonde, A., Aymemi, J., Urgelles, J. 2016. Mathematical modeling and learning trajectory: tools to support the teaching of linear algebra. In International Journal of mathematics Education in Science and Technology (online journal: http://dx.doi.org)

Corral, Michael. 2009. Trigonometry. Livonia (AS) : Michael Corral.

Elven, Soekirno. Buku Saku Matematika Trigonometri-1. Subang : Elven Soekirno.

Nadeem, Tamer. 2013. App Development for Smart Device. Norfolk (UK) : Old Dominion University. 
Pressman, Roger S. 2001. Software engineering: a practitioner's approach / Roger S. Press man.-5th edition. New York (AS): McGraw-Hill Higher Education.

Satriawan, Mirza. 2012. Fisika Dasar. Semarang. Penerbit Mirza Satriawan.

Android Developer. 2019. Android Sensor Overview. (2019,Juni, 17). Diakses dari http://developer.Android.com/guide/topics/sensors/sensors_overview.html.

Android Developer. 2019. Motion Sensors. (2019, Juni, 17) Diakses dari http://developer.Android.com/guide/topics/sensors/sensors_overview.html.

CoderzHeaven. 2019. How to Create a Custom Layout for Your Camera in Android?. ( 2019, Juni, 17) Diakses dari http://www.coderzheaven.com/2011/12/28/how-to-createa-custom-layout-for-your-camera-in-Android/. . 